\title{
RESPONS PERTUMBUHAN RUMPUT Brachiaria humidicola cv Tully DENGAN PEMBERIAN PUPUK ORGANIK BOKASHI KOTORAN AYAM PETELUR
}

\author{
Merlin Korejang, Selvie. D. Anis*, W. B. Kaunang, C. I. J. Sumolang. \\ Fakultas Peternakan Universitas Sam Ratulangi Manado
}

\begin{abstract}
ABSTRAK
Penelitian ini bertujuan untuk melihat respons pertumbuhan rumput Brachiaria humidicola cv Tully yang diberikan pupuk organik bokashi kotoran ayam petelur. Penelitian ini menggunakan Rancangan Acak Lengkap (RAL) yang terdiri dari 4 perlakuan dan 5 ulangan sehingga diperoleh 20 satuan percobaan. Perlakuan yang diberikan yaitu level pupuk organik bokashi yang terdiri dari B0 $=0$ ton/ha (kontrol), B1 = 2 ton/ha $(1,8$ $\mathrm{kg} /$ petak), B2 = 4 ton $/ \mathrm{ha}$ (3,6 kg/petak) dan B3 $=6 \mathrm{ton} / \mathrm{ha}(5,4 \mathrm{~kg} /$ petak $)$. Variabel yang diukur terdiri dari panjang stolon, jumlah buku, jumlah fitomer, jumlah anakan. Hasil analisis keragaman menunjukkan bahwa perlakuan memberikan pengaruh berbeda sangat nyata $(\mathrm{P}<0,01)$ terhadap panjang stolon, jumlah buku, jumlah fitomer dan berbeda nyata $(\mathrm{P}<0,05)$ terhadap jumlah anakan. Uji lanjut BNJ menunjukkan bahwa B1 $(1,8$ $\mathrm{kg} /$ petak), B2 (3,6 kg/petak), dan B3 (5,4 $\mathrm{kg} /$ petak) memiliki panjang stolon, jumlah fitomer dan jumlah anakan yang sangat nyata $(\mathrm{P}<0,05)$ lebih tinggi dari B0. Sedangkan B3 memiliki jumlah buku yang sangat nyata $(\mathrm{P}<0.01)$ lebih banyak dari B1 dan B0. Dari hasil penelitian ini disimpulkan bahwa pemberian pupuk organik bokashi kotoran ayam petelur sebanyak $1,8 \mathrm{~kg} /$ petak setara dengan 2 ton/ha memberikan hasil terbaik pada pertumbuhan rumput $B$. humidicola $c v$ Tully.
\end{abstract}

Kata Kunci: pertumbuhan, B. humidicola cv Tully, bokashi kotoran ayam,

\footnotetext{
*Korespondensi (corresponding author):
} Email:selvie_anis@yahoo.com

\begin{abstract}
GROWTH RESPONSE OF Brachiaria humidicola $c v$ Tully grass WITH ORGANIC FERTILIZER BOKASHI LAYING CHICKEN. This study aims to determine the growth response i.e stolon length, number of nodes, number of phytomers, and number of tillers of Brachiaria humidicola cv Tully with bokashi organic laying hens fertilizer. The completely randomized design was applied using four treatments and five replications for each treatment. The treatments were assigned level of bokashi. The levels of bokashi that $\mathrm{B} 0=0$ tons $/$ ha (control), B1 = 2 tons $/ \mathrm{ha}(1.8 \mathrm{~kg} / \mathrm{plot})$, $\mathrm{B} 2=4$ tons $/ \mathrm{ha}(3.6 \mathrm{~kg} / \mathrm{plot})$ and $\mathrm{B} 3=6$ tons $/ \mathrm{ha}(5.4 \mathrm{~kg} / \mathrm{plot})$. The variables measured consisted of stolon length, number of nodes, number of phyitomers, number of tillers. The Results of analysis of variance showed that treatment very significantly different $(\mathrm{P}<0.01)$ on stolon length, number of phyitomers, number of tillers and significantly different $(\mathrm{P}$ $<0.05)$ on the number of nodes. Test of Honest Significance Difference (HSD) showed that B1 (1.8 kg / plot), B2 (3.6 kg / plot), and B3 (5.4 $\mathrm{kg} \mathrm{/} \mathrm{plot)} \mathrm{have} \mathrm{higher} \mathrm{length} \mathrm{of} \mathrm{stolone,}$ number of phyitomers and number of tillers than B0. B3 and B2 had higher numbers of nodes than B0. It was concluded that the level $1.8 \mathrm{~kg} /$ plot organic fertilizer bokashi chicken laying equivalent to 2 tons/ha gave highest $B$. humidicola cv Tully growth response
\end{abstract}

Keywords: growth, $B$. humidicola $c v$ Tully, bokashi laying Chicken

\section{PENDAHULUAN}

Pada usaha peternakan, pakan merupakan salah satu masukan yang 
penting. Penyediaan pakan hijauan merupakan masalah utama bagi setiap usaha pengembangan ternak ruminansia. Keberhasilan usaha peternakan akan tergantung dari kecukupan tersedianya pakan hijauan yang berkelanjutan. Produktivitas ternak ruminansia dalam hal ini ternak sapi di Indonesia masih rendah. Penyediaan daging belum dapat memenuhi permintaan karena produksi yang rendah, hal ini disebabkan oleh masalah ketersediaan hijauan pakan unggul yang masih sangat kurang. Untuk meningkatkan produksi daging asal ternak ruminansia perlu upaya budidaya pakan hijaun sebagai pakan dasar ruminansia.

Rumput B. humidicola $c v$ Tully merupakan salah satu pakan hijauan unggul yang palatable dan dapat digunakan sebagai rumput potongan dan rumput penggembalaan. Rumput ini mampu menekan pertumbuhan gulma, adaptif terhadap pengairan yang kurang baik, toleran terhadap penggembalaan berat, dan mampu tumbuh pada lahan marjinal, sehingga berperan cukup besar bagi pengembangan dan penyediaan hijauan pakan di daerah tropis (Mansyur et al., 2007). Dalam upaya memenuhi kebutuhan pangan asal ternak sapi, akan diikuti dengan permintaan pakan hijauan. Untuk pemenuhan tersebut tanaman membutuhkan unsur hara yang cukup. Penggunaan pupuk anorganik selain harganya yang relatif lebih mahal, penggunaannya juga dapat berdampak negatif terhadap lingkungan. Pemupukan adalah usaha pemberian unsur hara pada tanah. Pupuk organik merupakan hasil peruraian sisa-sisa tumbuhan dan binatang, misalnya kompos dan pupuk kandang. Salah satu bahan baku pupuk organik yaitu limbah kotoran ternak ayam petelur. Pemanfaatan kotoran ayam petelur yang dikelolah menjadi pupuk organik (bokashi), selain tidak mencemari lingkungan juga dapat meningkatkan kesuburan tanah secara alamiah. Hasil penelitian Niknik et al. (2014), bahwa kotoran ayam petelur dengan dosis 98 g/rumpun dapat meningkatkan pertumbuhan dan produktivitas rumput Setaria sphacelata pada panen pertama dan kedua sedangkan hasil penelitian Kusuma (2015) pemberian dosis pupuk kotoran ternak ayam memberikan pengaruh terhadap jumlah anakan rumput Brachiaria pada dosis 40 ton $\mathrm{ha}^{-1}$ memberikan hasil yang tertinggi. Penambahan bahan organik dalam tanah akan menyebabkan aktifitas dan populasi mikroba dalam tanah meningkat, terutama yang berkaitan dengan aktifitas dekomposisi dan mineralisasi bahan organik.

Berdasarkan latar belakang diatas maka perlu dilakukan penelitian untuk mengetahui dan memperoleh data 
pengaruh pemberian bokashi kotoran ayam terhadap pertumbuhan rumput Brachiaria humidicola cv Tully.

\section{MATERI DAN METODE PENELITIAN}

Penelitian ini telah dilaksanakan di kebun percobaan milik Balai Pengkajian Teknologi Pertanian (BPTP) yang terletak di desa Talawaan Bantik, Kecamatan Wori Kabupaten Minahasa Utara. Rancangan yang digunakan adalah Rancangan Acak Lengkap (RAL) menurut Steel dan Torrie (1995) terdiri dari 4 perlakuan dan 5 ulangan sehingga diperoleh 20 satuan percobaan. Petak yang digunakan berukuran 3 x $3 \mathrm{~m}$, jumlah tanaman perpetak adalah 25 tanaman sehingga keseluruhan petak berjumlah 500 tanaman dengan jarak tanam $50 \mathrm{~cm}$ x $50 \mathrm{~cm}$.

Perlakuan yang diberikan adalah:

B0 = Tanpa Pemupukan (kontrol)

$\mathrm{B} 1=$ Level bokashi 1,8 kg/petak setara dengan 2 ton/ha

B2 = Level bokashi 3,6 kg/petak setara dengan 4 ton/ha

B3 = Level bokashi 5,4 kg/petak setara dengan 6 ton/ha

Bahan dan alat yang digunakan yaitu: Bahan: Anakan rumput B. humidicola $c v$ Tully, kotoran kering ayam petelur pada kandang battery, EM4, molasses, air sumur, kulit kopi, dedak halus, sekam padi dan tanah sebagai media tanam.

\section{Variabel Yang Diukur}

- Panjang stolon, pengukuran dilakukan menggunakan penggaris dengan satuan sentimeter $(\mathrm{cm})$, diukur mulai dari pangkal batang (permukaan tanah) sampai pada bagian ujung stolon

- Jumlah buku, yaitu menghitung jumlah buku yang bertambah per minggu setelah tanam.

- Jumlah Fitomer, yaitu menghitung jumlah fitomer yang tumbuh secara sempurna (akar,batang,daun) pada bagian stolon

- Jumlah Anakan (tiller), yaitu menghitung jumlah anakan yang tumbuh dari tanaman induk, sebanyak 3 tanaman per petak pengamatan

\section{Pembuatan Bokashi kotoran ayam}

Pembuatan pupuk bokashi kotoran ayam mengikuti prosedur menurut (Kusuma, 2012).

\section{Tahap pertama pembuatan pupuk bokashi kotoran ayam petelur}

\section{Persiapan bahan :}

a. Larutan EM4 (1/2 liter) + molasses (1/2 liter) + air dicampur merata.

b. Siapkan bahan- bahan pengisi :

Kotoran ayam petelur $(100 \mathrm{~kg})+$ dedak halus $(10 \mathrm{~kg})+$ sekam padi $(20$ 
kg), dan kulit kopi (60 kg), + air secukupnya.

c. Proses Pembuatan

Semua bahan pengisi dicampur secara bertahap mulai dari kulit kopi, sekam padi, dedak halus dan kotoran ayam. penyediaan wadah sebagai tempat pencampuran larutan EM4, air dan molases, bahan-bahan (EM4, air dan molases) dicampur secara homogen selanjutnya Siramkan larutan tersebut secara perlahan sampai merata ke dalam campuran bahan Kulit kopi, dedak halus, sekam padi dan kotoran ayam. Bahan dicampur berulang kali, lakukan hingga kandungan air di adonan mencapai $30-40 \%$. Tandanya, bila campuran dikepal, air tidak keluar dan bila kepalan dibuka, adonan tidak buyar. Hamparkan adonan di atas lantai kering dengan ketebalan 15 - $20 \mathrm{~cm}$, lalu tutup dengan karung goni atau terpal selama 2 - 4 minggu. Pengecekan suhu dilakukan setiap $5-6$ jam, suhu dipertahankan 40 - 500C. Apabila terjadi peningkatan suhu pada bahan olahan, maka dilakukan pembongkaran dengan membolak-balikan bahan tersebut dengan tujuan agar terjadi penurunan suhu. Pupuk sudah bisa digunakan apabila memiliki ciri yaitu bewarna hitam, gembur, tidak panas dan tidak berbau.

\section{Persiapan Lahan}

Lahan percobaan diolah menggunakan traktor mini untuk pembongkaran tanah dan rotary sehingga tersedia media tumbuh yang gembur dan homogen. Lahan yang sudah bersih dibagi menjadi petak-petak percobaan berukuran $3 \mathrm{~m}$ x $3 \mathrm{~m}$ atau seluas $9 \mathrm{~m} 2$, sebanyak 20 petak sebagai jumlah angka pengamatan.

\section{Penanaman}

Benih rumput B. humidicola $c v$ Tully berupa anakan rumput yang tumbuh lengkap sebagai satu fitomer (satu tanaman memiliki daun, batang dan akar). Anakan ditanam pada kedalaman $3 \mathrm{~cm}$ dengan jarak tanam 50 cm dan jarak antar petak 1 meter sehingga tiap petak berisi 25 tanaman sehingga keseluruhan petak berjumlah 500 tanaman. Setelah tanaman berumur satu minggu dilakukan penyiangan secara manual. Penyiraman dilakukan bila tidak ada hujan.

\section{Perlakuan}

Perlakuan pupuk bokashi aplikasikan merata sesuai level yang akan diuji pada petakan dua minggu sebelum ditanami anakan rumput dengan cara pupuk dihamburkan pada setiap petak kemudian ratakan dengan alat penggaruk. 


\section{Pengambilan Data}

Pengambilan data dilakukan dengan interval 1 minggu setelah tanaman berumur 2 minggu. Variabel yang diukur adalah panjang stolon, jumlah buku, jumlah fitomer dan jumlah anakan sampai pada saat tanaman berumur 6 minggu (42 hari) setelah tanam.

\section{HASIL DAN PEMBAHASAN}

Pengaruh perlakuan level bokashi kotoran ayam terhadap panjang stolon, jumlah buku, jumlah fitomer dan jumlah anakan disajikan pada Tabel 1.

\section{Panjang Stolon (cm)}

Hasil analisis keragaman menunjukkan bahwa level pupuk organik bokashi kotoran ayam memberikan pengaruh yang berbeda sangat nyata $(\mathrm{P}<0,01)$ terhadap panjang stolon. Hasil uji lanjut dengan BNJ menunjukkan perlakuan B3, B2 dan B1 berbeda tidak nyata $(\mathrm{P}>0,05)$ tetapi berbeda nyata $(\mathrm{P}<0,05)$ lebih panjang dibanding dengan perlakuan B0 (kontrol). Semakin tinggi level pupuk bokashi semakin meningkat pula perpanjangan stolon tanaman, diduga karena pupuk bokashi asal kotoran ayam mengandung unsur hara yang lengkap dan $\mathrm{C} / \mathrm{N}$ rasio yang ideal (Hartatik dan Widowati, 2006). Panjang stolon dari penelitian ini lebih rendah dibandingkan yang dilaporkan oleh Kurniawan et al. (2017) yang menggunakan pupuk organik menghasilkan panjang stolon $91,0 \mathrm{~cm}$ pada level pupuk 400 gram/polybag. Pada rumput yang tidak diberikan pupuk (B0) menunjukkan fase pertumbuhan yang lambat dibandingkan dengan perlakuan B1, B2 dan B3, pertumbuhan rumput pada perlakuan tersebut cukup cepat sehingga rumput merambat sudah melebihi batas

Tabel 1. Rataan Pengaruh Perlakuan Level Bokashi Kotoran Ayam Terhadap Panjang Stolon, Jumlah Buku, Julmah Fitomer, Jumlah Anakan

\begin{tabular}{ccccc}
\hline Perlakuan & Panjang Stolon & Jumlah Buku & Jumlah Fitomer & Jumlah Anakan \\
\hline B0 & $59,69^{\mathrm{b}}$ & $19,13^{\mathrm{b}}$ & $10,59^{\mathrm{b}}$ & $13,13^{\mathrm{b}}$ \\
B1 & $65,33^{\mathrm{ab}}$ & $19,07^{\mathrm{b}}$ & $13,53^{\mathrm{ab}}$ & $14,87^{\mathrm{ab}}$ \\
B2 & $71,37^{\mathrm{a}}$ & $21,47^{\mathrm{ab}}$ & $14,27^{\mathrm{a}}$ & $17,13^{\mathrm{ab}}$ \\
B3 & $70,32^{\mathrm{a}}$ & $22,73^{\mathrm{a}}$ & $15,73^{\mathrm{a}}$ & $21,20^{\mathrm{a}}$ \\
\hline
\end{tabular}

Keterangan: Superskrip yang berbeda pada kolom yang sama menunjukkan perbedaan yang sangat nyata $(\mathrm{P}<0,01)$. 
petak tempat pertumbuhannya. Bey dan Las (1991) menyatakan bahwa pertumbuhan tanaman ditentukan oleh laju pembelahan dan pembesaran sel dan suplai bahan-bahan organik dan anorganik untuk sintesa protoplasma dan dinding sel yang baru.

\section{Jumlah Buku}

Hasil analisis keragaman menunjukkan bahwa level pupuk organik bokashi kotoran ayam memberikan pengaruh yang berbeda sangat nyata $(\mathrm{P}<0,01)$ terhadap panjang stolon. Uji lanjut dengan BNJ menunjukkan perlakuan B3 dan B2 berbeda tidak nyata $(\mathrm{P}>0.05)$ tetapi berbeda nyata $(\mathrm{P}<0,05)$ dengan $\mathrm{B} 0$ dan $\mathrm{B} 1$. Pertambahan jumlah buku sejalan dengan pertambahan panjang stolon. Kedua variabel ini sangat erat hubungannya karena setiap buku yang bertumbuh menjadi titik pangkal perpanjangan stolon (Anis et al., 2015). Jumlah buku terbanyak pada perlakuan B3 diduga disebabkan oleh ketersediaan unsur hara yang telah mencukupi kebutuhan tanaman, bokashi kotoran ayam memiliki kandungan hara makro yang lengkap terutama nitrogen, bokashi kotoran ayam mengandung unsur $\mathrm{N}: 3,22 \%, \mathrm{P}: 3,24 \%, \mathrm{~K}: 4,47 \%$, S: 0,18\%, Mg: 0,86\%, Kadar air: 12,15\%, C-organik: $5,13 \%$ (Syamsuddin dan Faesal, 2003). Nitrogen merupakan salah satu faktor kunci yang membatasi pertumbuhan dan perkembangan tanaman (Ferguson et al., 2010), serta merupakan unsur hara utama juga dalam pembentukan bagian-bagian vegetatif tanaman seperti daun, batang dan akar. Padatnya individu baru pada perlakuan dapat menghambat perkembangan jumlah buku baru (Abdullah, 2009).

\section{Jumlah Fitomer}

Sebagaimana performan panjang stolon, pengaruh perlakuan terhadap jumlah fitomer menurut hasil uji lanjut menunjukan perlakuan level bokashi 5,4; 3,6; 1,8 kg/petak berbeda tidak nyata $(\mathrm{P}>0,05)$ tetapi berbeda nyata $(\mathrm{P}<0,05)$ dengan $0 \mathrm{~kg} /$ petak. Semakin banyak bokashi yang diberikan ke tanaman dalam penelitian ini menunjukkan respon yang baik untuk mendukung tanaman secara optimal. Sebagaimana pengaruhnya terhadap pertambahan panjang stolon dan jumlah buku, Suplai unsur hara makro N pada fase pertumbuhan awal tanaman sangat penting karena terkait erat dengan pembentukan khlorofil yang berperan utama dalam proses fotosintesis (Sholeh $e t$ al., 1997). Bokashi selain mengandung unsur hara N-P-K dan unsur mikro lainnya juga mengandung mikroorganisme aktif untuk proses dekomposisi bahan organik tanah menjadi tersedia untuk diserap tanaman (Higa dan Wididana, 1994). Setiap perkembangan buku akan 
menghasilkan anakan baru. Setiap buku pada stolon yang menyentuh tanah akan menghasilkan anakan baru, hal ini akan menambah jumlah fitomer. Pertambahan jumlah buku secara linier sangat membantu menaikkan produksi biomassa rumput $B$. humidicola $c v$ Tully karena pada setiap buku yang menyentuh tanah mengeluarkan anakan baru atau tiller yang memungkinkan tanaman untuk bertumbuh, menyebar dan menghasilkan daun dan batang baru, sebagai karakter tanaman yang berkembang dengan stolon (Anis et al., 2015).

\section{Jumlah Anakan (tiller)}

$\begin{array}{rrr}\text { Hasil analisis } & \text { keragaman } \\ \text { menunjukkan } & \text { bahwa } & \text { perlakuan }\end{array}$
memberikan pengaruh yang berbeda nyata $(\mathrm{P}<0,05)$ terhadap jumlah anakan, hasil uji lanjut dengan BNJ menunjukkan perlakuan B3 berbeda nyata $(\mathrm{P}<0,01)$ dengan perlakuan B0 tetapi berbeda tidak nyata dengan perlakuan B1 dan B2, ). Sutedjo dan Kartasapoetra (2004), menyatakan meningkatnya kandungan bahan organik pada tanah dapat meningkatkan kemantapan struktur pada tanah, hal ini menunjukkan bahwa kebutuhan $\mathrm{N}$ untuk menghasilkan anakan baru lebih banyak dari pada kebutuhan $\mathrm{N}$ untuk hasilkan daun baru (Sigar et al., 2014). Jumlah anakan dari penelitian ini lebih rendah dibandingkan yang dilaporkan oleh Kurniawan et al. (2017) menggunakan pupuk organik menghasilkan jumlah anakan 28,00; penelitian Ningalo et al. (2017) menggunakan pupuk nitrogen menghasilkan jumlah anakan 60,50 demikian juga dengan penelitian Kusuma (2016) yang mengunakan pupuk kotoran ayam menghasilkan jumlah anakan 26,75. Perbedaan hasil penelitian ini disebabkan faktor lingkungan tumbuh dari tanaman itu sendiri serta penggunaan jenis pupuk yang berbeda, dengan demikian akan membawah pengaruh yang berbeda terhadap pertumbuhan tanaman.

\section{KESIMPULAN}

Berdasarkan hasil penelitian yang telah dilaksanakan dapat disimpulkan bahwa pemberian pupuk organik bokashi kotoran ayam petelur sebanyak $1 \mathrm{~kg} /$ petak setara dengan 2 ton/ha memberikan pengaruh terbaik pada pertumbuhan rumput $B$. humidicola $c v$ Tully.

\section{DAFTAR PUSTAKA}

Abdullah, L. 2009. Pola pertumbuhan rumput signal (Brachiaria humidicola (Rendle) Schweick) pada padang penggembalaan dengan aplikasi sumber nutrien berbeda. Media Peternakan Vol 32 (1): 71-80 
Anis, S. D., D.A. Kaligis, and S. Pangemanan. 2015. Integration of cattle and koronivia grass pastura underneath mature coconuts in North Sulawesi Indonesia. J. Livestock Research for Rular Development Vol. 27(7):

Bey, A dan T. Las. 1991. Strategi Pendekatan Iklim Usaha Tani. Kapita Selekta Dalam Agroklimatologi. Dirjen Dikti Jakarta.

Ferguson, B. J., A. Indra Sumunar, S. Hayashi, Meng-Han Lin, Yu-Hsiang Lin, D. E. Reid dan P. M. Gressoff. 2010. Molecular analysis of legume nodule development and autoregulation. Journal of Integrative Plant Biology 52 (1): 61-76

Hartatik dan Widowati. 2006. Pupuk Kandang, Pupuk Organik Dan Pupuk Hayati. Balai Besar Litbang Sumberdaya Lahan Pertanian, Badan Penelitian Dan Pengembangan Pertanian, Bogor. Hal 59-82

Higa, T. dan G.N. Wididana. 1994. Effective Microorganisme: Dimensi Baru dalam Kyusei Nature Farming. MajalahTumbuh 1 (94): 39-14

Kurniawan, D., S.D. Anis, Rustandi, dan W.B. Kaunang. 2017. Pengaruh umur pemotongan dan level pupuk organik terhadap pertumbuhan vegetatif rumput Brachiaria humidicola. Jurnal Zootek Vol 37 (2): 259-267.

Kusuma, M. E., 2012. Pengaruh beberapa jenis pupuk kandang terhadap kualitas bokashi. Jurnal Ilmu Hewan Tropika Vol 1 (2): 41-46

Kusuma, M.E. 2015. Pengaruh Dosis Pupuk Kotoran Ternak Ayam Terhadap Pertumbuhan Dan Produksi Rumput Brachiaria humidicola pada pemotongan pertama. Jurnal Ilmu Hewan Tropika Vol 4 (1):49-54

Kusuma, M. E. 2016. Efektifitas pemberian dosis pupuk kotoran ternak ayam terhadap produksi rumput Brachiaria humidicola pada pemotongan pertama dan kedua. Jurnal Ilmu Hewani Tropika Vol 5 (1): 2301-7783

Mansyur., L. Abdullah, H. Djuned, A.R. Tarmidi, T. Dhalika. 2007. Konsentrasi amonia dan asam lemak terbang rumput Brachiaria humidicola (Rendle) Schweick pada berbagai interval pemotongan (In Vitro). Jurnal Ilmu Ternak 7(1): 64-68

Ningalo, R. R., Rustandi, D. A. Kaligis., N. Bawole. 2017. Pengaruh defoliasi dan level pupuk nitrogen terhadap performans rumput Brachiaria humidicola (Rendle) Schweick cv. Tully. Jurnal Zootek Vol. 37 (1): 2532

Niknik., Achmad Marzuki., Bambang Sugiyanto. 2014. Pemberian pupuk organik kotoran ayam petelur dan konsentrasi em4 dalam meningkatkan produksi rumput setaria (Setaria Sphacelata). Jurnal Ilmiah Inovasi 14 (1): 65-74

Sholeh., D. Nursyamsi, S.J. Adiningsih. 1997. Pengelolaan Bahan Organik dan Nitrogen untuk Tanaman Padi dan Ketela Pohon pada Lahan Kering yang Mempunyai Tanah Ultisol di Lampung. Prosiding. Pertemuan Pembahasan dan Komunikasih Hasil Penelitian Tanah dan Agroklimat, Bidang Kimia dan Biologi Tanah Departemen Pertanian. Hal 193206. 
Sigar, N.V.F., D.A. Kaligis, W.B. Kaunang, dan S.S. Malalantang. 2014. Pengaruh pemberian pupuk $\mathrm{N}-\mathrm{K}$ terhadap hasil bahan kering dan protein kasar rumput Brachiaria humidicola cv. Tully dan Pennisetum purpureum cv. Mott. Jurnal zootek 34(2): 109 113

Steel, R.G.D and J.H. Torrie. 1995. Prinsip dan Prosedur Statistika Suatu Pendekatan Biometrik, Jakarta. Terjemahan PT Gramedia.

Sutedjo, M.M dan A.G. Kartasapoetra. 2004. Pengantar Ilmu Tanah Terbentuknya Tanah dan Tanah Pertanian. Rineka Cipta. Jakarta.

Syamsuddin dan Faesal. 2003. Pengaruh berbagai takaran bokashi terhadap hasil tanaman jagung. Jurnal Stigma. Vol 11(4): 345-34. 